Jurnal Biologi dan Pembelajarannya, Vol 7 No 1, April 2020. Pp: 1-6

e-ISSN: $2406-8659$

\title{
PENGEMBANGAN ENSIKLOPEDIA TUMBUHAN PAKU SEBAGAI SUMBER BELAJAR KEANEKARAGAMAN HAYATI
}

\author{
Ayu Renita, Eni Setyowati ${ }^{*}$, Arbaul Fauziah, Nanang Purwanto \\ Jurusan Tadris Biologi, Fakultas Tarbiyah dan Ilmu Keguruan, IAIN Tulungagung \\ ${ }^{*}$ Email: enistain76@yahoo.com
}

\begin{abstract}
Abstrak
Penelitian ini bertujuan untuk mengembangkan ensiklopedia tumbuhan paku sekaligus mengetahui tingkat validitasnya. Jenis penelitian ini adalah R\&D dengan menggunakan model pengembangan ADDIE. Hasil validasi ahli materi, ahli media, dan dosen biodiversitas masing-masing diperoleh persentase sebesar 83\% (sangat valid), $77 \%$ (valid), dan $97 \%$ (sangat valid). Hasil uji coba lapangan (pre test dan post test) dianalisis menggunakan uji-t ( $t$-test) menunjukkan nilai signifikansi sebesar 0,001 $<0,05$. Sementara respon siswa terhadap efektivitas ensiklopedia tumbuhan paku sebagai sumber belajar diperoleh persentase sebesar 86,50\%. Dengan demikian, ensiklopedia tumbuhan paku dapat diimplementasikan sebagai sumber belajar tambahan pada materi keanekaragaman hayati.
\end{abstract}

Kata kunci-Ensiklopedia, Sumber Belajar, Tumbuhan Paku

\section{PENDAHULUAN}

Tumbuhan merupakan jenis makhluk hidup yang memiliki tingkat keanekaragaman cukup tinggi. Salah satu contoh tumbuhan yang memiliki keanekaragaman tinggi adalah tumbuhan paku. Tumbuhan paku merupakan kelompok tumbuhan yang memiliki jumlah spesies yang cukup banyak. Atsushi E., dkk (2012) menyebutkan bahwa sepertiga spesies tumbuhan paku di dunia (4.500 spesies) terdapat di kawasan Asia [1]. Sekitar 1.250-1.500 jenis tumbuhan paku tercatat tumbuh di Indonesia dengan 515 jenis di antaranya tersebar di Pulau Jawa [2].

Keanekaragaman tumbuhan paku termasuk dalam kajian biologi, baik pada tingkatan sekolah menengah maupun perguruan tinggi. Pada jenjang sekolah menengah pertama, materi mengenai tumbuhan paku tidak dibahas secara spesifik, namun termuat dalam KD 3.1 kelas VII mengenai klasifikasi makhluk hidup. Sementara pada jenjang sekolah menengah atas, kajian tentang tumbuhan paku mulai mendapat ulasan cukup dalam yang dimuat dalam KD 3.8 kelas X mengenai pengelompokan tumbuhan [3]. Sedangkan pada jenjang perguruan tinggi, kajian mengenai tumbuhan paku banyak dibahas pada mata kuliah biodiversitas. Sejauh ini, buku yang secara khusus membahas mengenai tumbuhan paku terbatas jumlahnya. Selain itu, sebagian besar buku yang memuat materi tersebut tidak disertai dengan gambar terbaru. Gambar yang disajikan hanya mencangkup sebagian kecil tumbuhan paku sehingga tidak dapat merepresentasikan keanekaragaman tumbuhan paku. Berdasarkan hal tersebut, maka perlu adanya sebuah sumber belajar yang dapat memenuhi kebutuhan pelajar dalam mengenal tumbuhan paku, misalnya dalam bentuk ensiklopedia.

Ensiklopedia merupakan kumpulan tulisan yang berisi beragam informasi secara lengkap yang disusun berdasarkan abjad dan dicetak dalam bentuk buku [4]. Ensiklopedia bertujuan untuk merangkum dan mengumpulkan berbagai informasi sekaligus menarik minat pembaca [5]. Ensiklopedia dipilih sebagai produk dari pengembangan ini karena ensiklopedia identik dengan gambar, terkesan lebih ringan, menarik, dan ringkas. Hal ini juga didukung oleh hasil penelitian yang dilakukan oleh Hanif Nurmansyah (2015) yang menunjukkan bahwa penggunaan bahan ajar berbasis ensiklopedia mampu meningkatkan motivasi belajar siswa [6].

Melalui penelitian ini diharapkan dapat diperoleh produk berupa ensiklopedia tumbuhan paku yang dapat dimanfaatkan oleh pelajar maupun masyarakat umum untuk mengenal tumbuhan paku, baik morfologinya, manfaatnya, maupun keanekaragamannya.

\section{METODE PENELITIAN}

Penelitian ini bertujuan untuk mengembangkan sumber belajar berupa ensiklopedia tumbuhan paku dan menilai tingkat validitasnya. Jenis penelitian ini merupakan penelitian dan pengembangan (Research and Development) yang mengacu pada model pengembangan ADDIE. Tahapan ini diawali dengan proses analisis (Analysis), desain (Design), pengembangan (Development), implementasi (Implementation), dan yang terakhir adalah evaluasi (Evaluation). Dalam penelitian ini, tahapan tersebut hanya dilakukan hingga tahap implementasi. 
Jurnal Biologi dan Pembelajarannya, Vol 7 No 1, April 2020. Pp: 1-6

e-ISSN: $2406-8659$

Penilaian terhadap kelayakan dan validitas ensiklopedia tumbuhan paku dilakukan oleh tiga validator yang terdiri dari ahli materi, ahli media, dan praktisi pembelajaran (dosen mata kuliah biodiversitas). Skor hasil penilaian dianalisis secara deskriptif kuantitatif dengan menggunakan rumus seperti berikut.

$$
\mathrm{NP}=\frac{\mathrm{R}}{\mathrm{SM}} \times 100 \%
$$

$\begin{array}{ll}\text { NP } & \text { : Nilai presentase } \\ \text { R } & : \text { Skor hasil penilaian } \\ \text { SM } & : \text { Skor maksimal }\end{array}$

Nilai presentase yang diperoleh kemudian dikonversi menjadi data kualitatif. Konversi skor mengacu pada pedoman konversi menurut Purwanto (2012) yang disajikan dalam tabel 1 berikut ini.

Tabel 1. Tabel Pedoman Konversi Skor

\begin{tabular}{lll}
\hline No & Interval Skor & Keterangan \\
\hline 1. & $81 \% \leq \mathrm{NP}<100 \%$ & Sangat Valid \\
2. & $62 \% \leq \mathrm{NP}<81 \%$ & Valid \\
3. & $43 \% \leq \mathrm{NP}<62 \%$ & Cukup Valid \\
4. & $33 \% \leq \mathrm{NP}<43 \%$ & Kurang Valid \\
5. & $\mathrm{NP}<33 \%$ & Sangat Kurang Valid \\
\hline
\end{tabular}

(Purwanto, 2012 dikutip dalam Fitri W. 2018)

Data hasil uji coba lapangan berupa nilai pretest dan posttest dianalisis menggunakan uji-t untuk mengetahui ada tidaknya pengaruh penggunaan ensiklopedia tumbuhan paku terhadap hasil belajar siswa.

\section{HASIL DAN PEMBAHASAN}

Analisis

Dalam tahap analisis (analysis), dilakukan proses analisis kebutuhan siswa terhadap ensiklopedia tumbuhan paku. Analisis kebutuhan dilakukan dengan memberikan angket kepada 30 responden yang terdiri dari siswa SMP, SMA, dan Mahasiswa. Hasil analisis kebutuhan menunjukkan bahwa 73\% responden (22 dari 30 responden) mengaku tidak mengetahui jenis-jenis tumbuhan paku dan 90\% responden (27 dari 30 responden) menyebutkan jika lebih menyukai sumber belajar yang dilengkapi dengan foto atau gambar asli yang berwarna (tabel 2).

Tabel 2. Hasil Analisis Kebutuhan

\begin{tabular}{|c|c|c|c|}
\hline \multirow{2}{*}{ No. } & \multirow{2}{*}{ Pernyataan } & \multicolumn{2}{|c|}{ Presentase (\%) } \\
\hline & & Positif $^{(*)}$ & Negatif ${ }^{(*)}$ \\
\hline 1. & Pengetahuan mengenai tumbuhan paku & 27 & 73 \\
\hline 2. & Minat terhadap sumber belajar bergambar dan berwarna & 90 & 10 \\
\hline 3. & Respon terhadap adanya sumber belajar mengenai tumbuhan paku & 90 & 10 \\
\hline
\end{tabular}

\section{Keterangan:}

Positif $^{(*)} \quad$ : Setuju/Pernah/Mengetahui

Negatif $^{(*)} \quad$ : Tidak Setuju/ Tidak Pernah/ Tidak Mengetahui

\section{Desain}

Dalam tahap ini dilakukan proses penyusunan materi dan perancangan produk. Materi dalam ensiklopedia berasal dari hasil identifikasi tumbuhan paku yang diperoleh di Kawasan Air Terjun Parangkikis Pagerwojo Tulungagung. Dalam ensiklopedia tumbuhan paku disajikan deskripsi masing-masing spesies tumbuhan paku (meliputi deskripsi morfologi, klasifikasi, nama lokal, habitat, persebaran dan manfaatnya). Ensiklopedia tumbuhan paku terdiri dari 3 bagian pokok yaitu bagian awal, inti, dan penutup (tabel 3 ).

Tabel 3. Komponen Ensiklopedia Tumbuhan Paku

\begin{tabular}{lll}
\hline No & Bagian & Komponen \\
\hline \hline 1. & Awal & Sampul /cover \\
\hline
\end{tabular}


Jurnal Biologi dan Pembelajarannya, Vol 7 No 1, April 2020. Pp: 1-6

e-ISSN: $2406-8659$

\begin{tabular}{|c|c|c|}
\hline & & Halaman judul \\
\hline & & Petunjuk penggunaan \\
\hline & & Kata pengantar \\
\hline & & Daftar isi \\
\hline & & Daftar gambar \\
\hline & & Pendahuluan (sejarah tumbuhan paku) \\
\hline & Inti & Kondisi lingkungan Air Terjun Parangkikis \\
\hline & IntI & Tinjauan umum tumbuhan paku \\
\hline & & Keanekaragaman tumbuhan paku \\
\hline & & Glosarium \\
\hline 3. & Penutup & Daftar pustaka \\
\hline & & Profil penulis \\
\hline
\end{tabular}

\section{Pengembangan}

Dalam tahap ini rancangan yang telah dibuat pada tahap sebelumnya direalisasikan menjadi produk yang siap untuk digunakan. Ensiklopedia tumbuhan paku terdiri dari 50 halaman beserta cover dan dicetak dengan ukuran standar ISO yaitu A4 (21 cm x 29,7 cm). Bagian sampul dicetak menggunakan kertas art paper 125 gr sementara bagian isi dicetak dengan jenis kertas HVS 100 gr (gambar1).

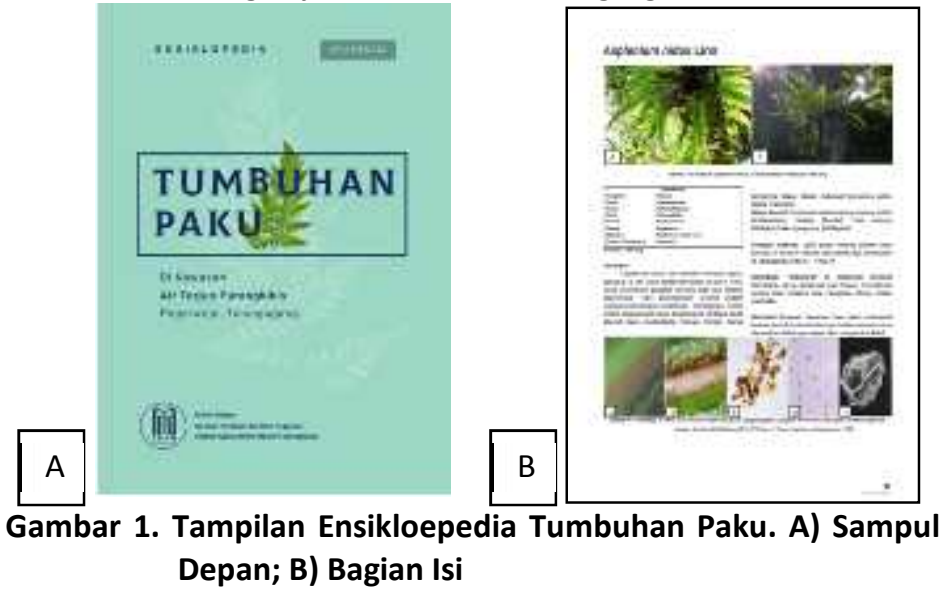

Dalam tahap pengembangan juga dilakukan penilaian oleh validator untuk mengetahui kualitas atau validitas ensiklopedia tumbuhan paku. Validasi produk oleh ahli materi dimaksudkan untuk memperoleh penilaian terhadap kualitas isi dari ensiklopedia tumbuhan paku. Penilaian ahli materi meliputi cakupan materi, akurasi materi, dan tata bahasa disajikan dalam gambar 2 berikut ini.

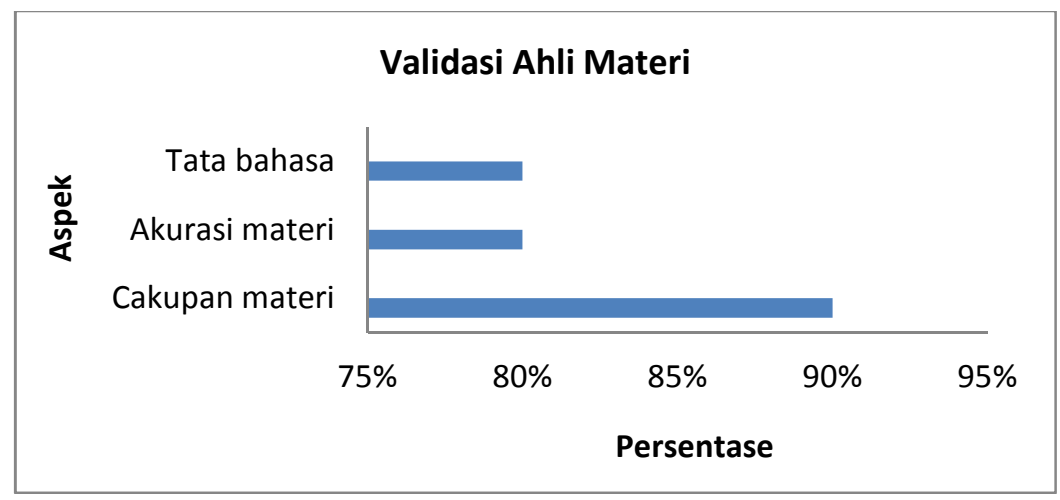

Gambar 2. Grafik Penilaian Ahli Materi

Berdasarkan data tersebut, dapat diketahui bahwa hasil penilaian ahli materi pada aspek cakupan materi memperoleh presentase $90 \%$ dengan kategori sangat valid. Hal ini menunjukkan bahwa ensiklopedia tumbuhan paku memiliki cakupan materi yang relevan dengan materi keanekaragaman hayati dan dapat digunanakan untuk membantu proses pengamatan tumbuhan paku di lingkungan sekitar. Sementara untuk 
Jurnal Biologi dan Pembelajarannya, Vol 7 No 1, April 2020. Pp: 1-6

e-ISSN: $2406-8659$

aspek akurasi materi, diperoleh presentase sebesar $80 \%$ dengan kriteria valid. Hal ini berarti ensiklopedia memiliki tingkat keakuratan konsep, istilah yang digunakan, dan kesesuaian ilustrasi yang sudah baik. Untuk aspek tata bahasa, ensiklopedia tumbuhan paku memperoleh presentase sebesar $80 \%$ dengan kategori valid. Pada aspek kebahasaan, ensiklopedia telah menggunakan bahasa, dan penulisan yang baik sesuai kaidah yang berlaku. Persentase rata-rata dari keseluruhan aspek materi diperoleh nilai sebesar $83 \%$ dengan kriteria valid.

Validasi kedua dilakukan oleh ahli media yang bertujuan untuk memperoleh penilaian terhadap kualitas penyajian ensiklopedia tumbuhan paku. Aspek penilaian ahli media meliputi aspek penyajian secara umum, desain, dan tampilan fisik (gambar 3).

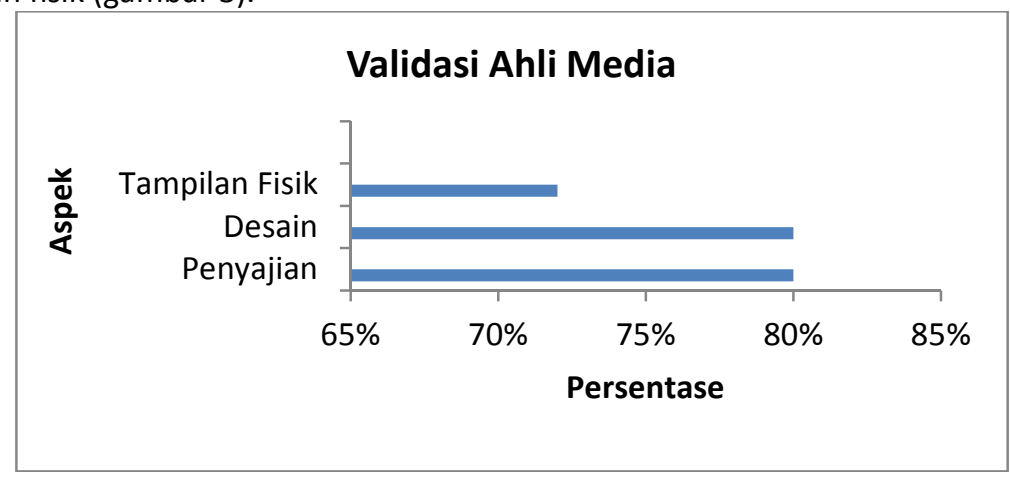

Gambar 3. Grafik Penilaian Ahli Media

Penilaian ahli media terhadap aspek penyajian secara umum menunjukkan presentase sebesar $80 \%$ dengan kategori valid. Hal ini berarti bahwa secara umum ensiklopedia memiliki penyajian materi yang sistematis dan lengkap sesuai daftar isi. Sementara pada aspek desain diperoleh presentase sebesar $80 \%$ dengan kategori valid. Dalam hal desain, ensiklopedia tumbuhan paku memiliki layout, kefokusan gambar, proporsi dan komposisi warna yang baik. Desain merupakan kunci dari kemenarikan suatu media. Wachidah (2015), menuliskan bahwa antara desain sampul depan dan belakang sebaiknya membentuk kesatuan yang utuh [8]. Pemilihan warna, logo maupun gambar harus ditampilkan secara harmonis dan seimbang. Desain sampul harus memiliki kontras yang cukup, kombinasi warna yang bagus, serta menggunakan ilustrasi yang mampu menggambarkan isi dari endiklopedia. Sementara dari aspek tampilan fisik, diperoleh presentase sebesar $72 \%$ dengan kategori valid. Hal ini menunjukkan bahwa ensiklopedia tumbuhan paku memiliki kualitas cetakan dan penjilidan yang baik, kuat, dan tidak mudah lepas. Persentase rata-rata dari ketiga aspek penilaian oleh ahli media diperoleh nilai sebesar $77 \%$ dengan kategori valid.

Penilaian kelayakan ensiklopedia tumbuhan paku yang ketiga dilakukan oleh praktisi pembelajaran (dosen biodiversitas). Aspek penilaian oleh dosen biodiversitas meliputi aspek cakupan materi, akurasi materi, tata bahasa, dan tampilan fisik (gambar 4).

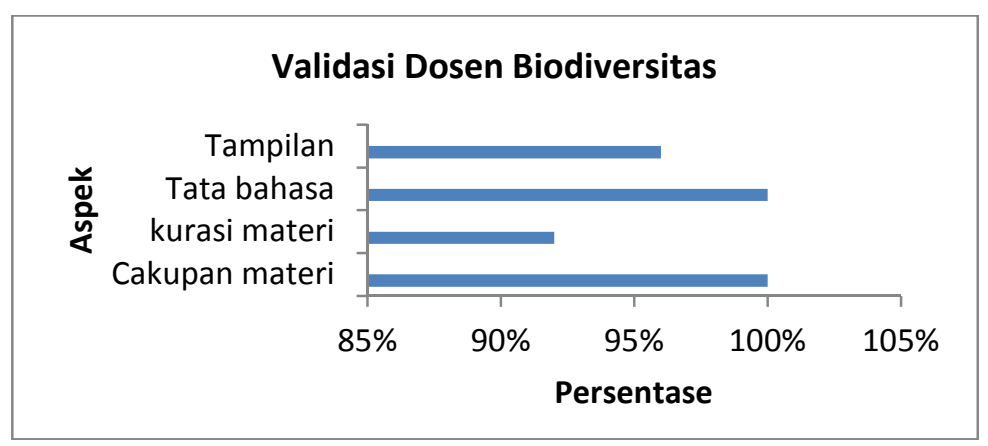

Gambar 4. Grafik Penilaian Dosen Biodiversitas

Secara keseluruhan penilaian dosen biodiversitas terhadap kualitas ensiklopedia tumbuhan paku menunjukkan angka yang sangat tinggi. Presentase terbesar terdapat pada aspek cakupan materi dan tata bahasa yang memperoleh presentase 100\%. Ayatusa'adah dan Nor A. Dewi (2017) menyebutkan bahwa sumber belajar atau media pembelajaran yang baik seharusnya memiliki kemampuan untuk membuat konkrit konsep yang abstrak, hal ini sesuai denggan isi ensiklopedia tumbuhan paku yang menyajikan materi dengan luas dan detail disertai gambar tumbuhan asli (dalam bentuk habitus secara utuh maupun bagian-bagian khusus seperti bentuk tepi daun, pertulangan daun, dan spora) sehingga mampu memberikan gambaran dan informasi tambahan bagi pembaca [9]. Rata-rata persentase dari keseluruhan aspek yang dinilai oleh dosen biodiversitas memperoleh nilai sebesar $97 \%$ dengan kategori sangat valid. 
Jurnal Biologi dan Pembelajarannya, Vol 7 No 1, April 2020. Pp: 1-6

e-ISSN: $2406-8659$

Secara umum, penilaian ahli materi, ahli media, dan dosen biodiversitas menunjukkan angka yang cukup tinggi. Secara keseluruhan ensiklopedia tumbuhan paku memperoleh presentase rata-rata sebesar $85,67 \%$ dengan kategori sangat valid sehingga layak untuk diimplementasikan sebagai sumber belajar tambahan. Rekapitulasi hasil validasi dari ketiga validator dirangkum dalam tabel 3 berikut ini.

Tabel 3. Rekapitulasi Hasil Penilaian

\begin{tabular}{|c|c|c|c|}
\hline No & Penilai/validator & Presentase (\%) & Kategori Validitas \\
\hline 1. & Ahli materi & 83 & Sangat valid \\
\hline 2. & Ahli media & 77 & Valid \\
\hline 3. & Dosen biodiversitas & 97 & Sangat valid \\
\hline \multicolumn{2}{|c|}{ Rata-Rata Keseluruhan } & 85,67 & Sangat valid \\
\hline
\end{tabular}

\section{Implementasi}

Tahap implementasi dalam penelitian ini dilakukan dengan uji coba kelompok kecil. Uji coba dilakukan dengan memberikan sejumlah soal latihan (pretest dan posttest) kepada 10 responden yang berada pada jenjang SMP, SMA, dan mahasiswa. Rata-rata nilai pretest adalah sebesar 56,9 sedangkan rata-rata nilai posttest adalah 88,6 . Hasil analisis $t$-test menunjukkan nilai signifikansi sebesar 0,001 . Oleh karena nilai signifikansi 0,001 <0,05, maka dapat disimpulkan bahwa keberadaan ensiklopedia tumbuhan paku sebagai sumber belajar tambahan memberikan pengaruh positif terhadap pemahaman siswa. Hal ini sangat penting karena tujuan utama dari sebuah sumber belajar adalah untuk meningkatkan hasil belajar siswa (A Nurafifah, dkk., 2017).

Uji coba juga dilakukan untuk mengetahui respon pengguna terhadap kelayakan ensiklopedia tumbuhan paku. Aspek yang dinilai oleh responden antara lain kemudahan pemahaman, kegunaan atau kebermanfaatan, minat terhadap ensiklopedia, dan penyajian ensiklopedia (gambar 5).

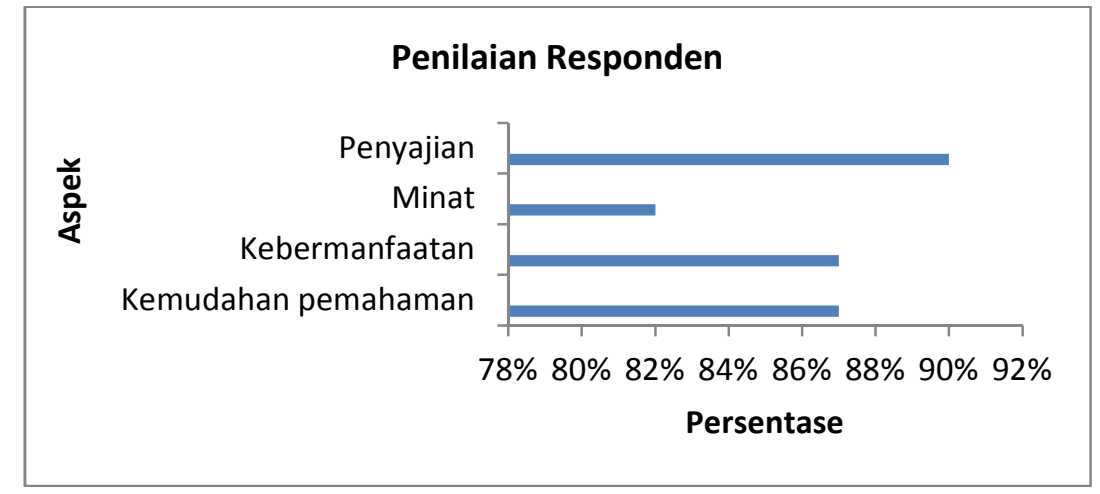

Gambar 5. Grafik Penilaian Responden

Penilaian yang diberikan oleh responden menunjukkan nilai yang cukup tinggi. Secara keseluruhan, ensiklopedia tumbuhan paku memiliki persentase rata-rata sebesar $86,50 \%$ dengan kriteria sangat valid atau sangat baik.

\section{SIMPULAN}

Ensiklopedia disusun berdasarkan hasil identifikasi tumbuhan paku di kawasan Air Terjun Parangkikis. Hasil validasi ahli materi, ahli media, dan dosen biodiversitas masing-masing diperoleh persentese sebesar $83 \%$ (sangat valid), 77\% (valid), dan 97\% (sangat valid). Berdasarkan hasil validasi dan uji coba lapangan, dapat disimpulkan bahwa ensiklopedia tumbuhan paku mampu meningkatkan hasil belajar siswa dan layak untuk diimplementasikan sebagai sumber belajar tambahan.

\section{SARAN}

\section{UCAPAN TERIMA KASIH}

Ucapan terimakasih ditujukan kepada Jurusan Tadris Biologi Fakultas Tarbiyah dan Ilmu Keguruan IAIN Tulungagung yang telah memberikan dukungan selama proses penelitian. Terimakasih juga ditujukan kepada 
Jurnal Biologi dan Pembelajarannya, Vol 7 No 1, April 2020. Pp: 1-6

e-ISSN: $2406-8659$

Kepala Desa Gambiran Kecamatan Pagerwojo Tulungagung yang telah memberikan izin untuk melakukan penelitian di Kawasan Air Terjun Parangkikis.

\section{DAFTAR PUSTAKA}

[1] Nurafifah A., Budi A. S., dan Siahaan B. Z. 2017. Developing Wave Encyclopedia based on Scientific Approach. Journal of Physics. Conf. Series 895012018.

[2] Lusiana, N., Wahyu, P., Abdulkadir R. 2015. Pemanfaatan Pteridophyta Kawasan Hutan Pacet Taman Hutan Raya (Tahura) Raden Soerjo Kecamatan Pacet Kabupaten Mojokerto Sebagai Sumber Belajar Biologi SMA. Jurnal Pendidikan Biologi Indonesia, 1 (2), 169-176.

[3] Permendikbud No. 24 Tahun 2016 tentang KI dan KD Kurikulum 2013.

[4] Nuraida, D. dan Umi M. Nisa. 2017. Pengembangan Ensiklopedia Morfologi, Anatomi dan Fisiologi pada Tumbuhan Berkarakter Khusus. Proceeding Biology Education Conference, 14 (1), 503-507.

[5] Zulkarnain, Z., A. S. Budi., I. M. Astra, dan Mujadi. 2019. Development of Work and Energy Encyclopedia Based on Science Technology and Society. Journal of Physics. Conf. Series 1185012046.

[6] Nuurmansyah, H. 2015. Pengembangan Bahan Ajar Berbasis Ensiklopedia Ilmu Pengetahuan Sosial pada Materi Kerajaan Hindu-Budha dan Islam Untuk Peningkatan Motivasi Belajara Peserta Didik Kelas V di Madrasah Ibtidaiyah Anbaul Ulum Pakis - Kabupaten Malang. Skripsi, Program Studi Pendidikan Guru Madrasah Ibtidaiyah, UIN Malang, 1-138.

[7] Ramadhani, W. P., dkk. 2015. Kegrafikan Modul Pembelajaran Fisika Berbasis Multirepresentasi. Semnas Fisika dan Pembelajarannya, 1-9.

[8] Ayatusa'adah dan Nor A. Dewi. 2017. Inventarisasi Tumbuhan Paku (Pteridophyta) di Kawasan Kampus IAIN Palangkaraya Sebagai Alternatif Media Pembelajaran Materi Klasifikasi Tumbuhan. EduSains: Jurnal Pendidikan Sains dan Matematika, 5 (2), 50-61.

[9] Ebihara, A., dkk. 2012. Rare and Threatened Pteridophytes of Asia 1. An Enumeration of Narrowly Distributed Taxa. National Science, 38 (3), 93-119.

[10] Wijarini, F. dan Zulfadli. 2018. Desain Pengembangan Ensiklopedia Tumbuhan Obat Berbasis Potensi Lokal di Kota Tarakan. Jurnal Inovasi Pendidikan Sains, 9 (1), 11-16. 